DOI: $10.1515 /$ hssr -2015-0017

HSS IV.2 (2015)

\title{
The Monastic Hermitage in the End of 19th Century French Literature: a New Identity Space
}

Mickaëlle Cedergren*

University of Stockholm, Sweden

\begin{abstract}
Through a comparative reading of three novels of the late nineteenth century, namely Le Disciple, A rebours and Un homme libre, the monastic hermitage has emerged as a common place in which the protagonists of the novels, in search for a spiritual space, let themselves be shaped and transformed by the materiality of places. Through the consideration of the specific features of these closed and sacred sanctuaries, as well as the identity and the dream of the end of the $19^{\text {th }}$ century man, a new literature searching for an ideal will appear openly.
\end{abstract}

Keywords

Monastic Hermitage, $19^{\text {th }}$ century French literature, Decadence, Identity Space, Huysmans, Barrès, Bourget.

A blue sheen radiates from my clothes.

Midwinter.

Jangling tambourines of ice.

I close my eyes.

There is a soundless world there is a crack where dead people are smuggled across the border.

(Tranströmer, Midwinter)

\section{The monastic space or the scenery issue}

Whether the Fontenay solitary retreat where des Esseintes lives, or the Guy- de- la Brosse hermitage where the scientist Sixte lives or that of St-

Associate professor of French, Romanska och klassiska institutionen, Stockholms universitet, SE- 10691 Stockholm, mickaelle.cedergren@su.se 
Mickaëlle Cedergren, The monastic Hermitage in the end of century...

HSS, vol. IV, no. 2 (2015): 103-118

Germain in which Philippe and his friend Simon settled, the enclosed space of these novels follows meticulously defined norms. The motivation driving those men to cloister is certainly different but many convergences emerge nonetheless. If des Esseintes, the esthete, only cares about living a monk's sensation, Sixte, the scientist, considers his hermitage as an anchor to cultivate his split with the world by devoting his life to sciences (Bourget, 2010: 72). As for Philippe, the egotistic, he aspires to a life of meditation and communion and his quest, therefore naturally, will find a home base in the St-Germain hermitage. Strongly disagreeing with their time, those recluses live on the fringes of the society they want to distance themselves from.

To begin with, we can repeat with John Vilcot that those "hermitic characters have much model value. They are paroxysmal images of secession where is asserted and satisfied an intimate imagination that a strong life discomfort and an acute disagreement with its time exacerbate" (Vilcot, 1988: 32). ${ }^{1}$ As a proof, Huysmans does not hide from the reader the purpose of des Esseintes' isolation:

Il avait ainsi les avantages de la claustration et il en évitait les inconvénients : la discipline soldatesque, le manque de soins, la crasse, la promiscuité, le désœuvrement monotone. De même qu'il avait fait de sa cellule, une chambre confortable et tiède, de même il avait rendu sa vie normale, douce, entourée de bien être, occupée et libre (Huysmans, 2004: 102). ${ }^{2}$

In short, des Esseintes does not want to live like a monk; he acknowledges that he lacks the "call for the grace state", but is eager to experience the feelings of the monk with whom "he was feeling a real sympathy" (Ibid.) Finally, the hope to enjoy this state of mind, to which he combines "an immense fatigue", a "need for contemplation" (Ibid.) and a sacred touch, constitutes the core of his approach. Behind the hermitage scenes, des Esseintes therefore aspires to go beyond this "convent atmosphere." Besides the striking atmosphere of this space, these places also invite the character to adopt a materiality that will, perhaps against his will, lead him to another dimension, that of inwardness. This interaction between materialization and internalization, between flesh and spirit, also developed subsequently in writing about 
Mickaëlle Cedergren, The monastic Hermitage in the end of century...

HSS, vol. IV, no. 2 (2015): 103-118

mystical naturalism ${ }^{3}$ (Peylet, 1987: 19-32), will be the heart of our thinking.

By covering his refuge with a monastic garment and ritual, the author, whoever he is, takes a risk, that of making his character penetrate this inner state to apprehend and who knows, to have access to this up-there, to this divine kingdom of which we will find the illustration clearly accounted for in En route. Just as des Esseintes turned his genius to reproduce "natural flowers imitating fake flowers" (Huysmans, 2004: 124) he has reproduced a monastic setting that imitates a fake one. With the loss of its primary functions, the cloistered space is again akin to a framework devoid of mind. But the spirit of the place will return quickly galloping to seize its host and make him captive. This outdoor confinement sees its center move to come and live inside the protagonist. This transfiguration seems to be the natural outcome of these three novels.

The end of century character, thirsting for spiritual values, will naturally seek refuge in a high spiritual place. However, if it were only a question of refuge, asylum, privacy, or solitude, other places - like any imprisonment or incarceration space - could just as well do the trick. Therefore, the realistic look of the fence is not the only cause (LimatLetellier, 2001: 448). The mystical dimension of this place is extended, at a closer look, in parallel, insidiously, and finally in a less surprising manner.

Through the analysis of the specifics of these monastic hermitages will emerge the identity and the dream of the end of the $19^{\text {th }}$ century man.

\section{The monastic Hermitage, a mechanized and ritualized lifestyle}

In Gerard Peylet's classic study Les Evasions manquées (1986), "spiritual and religious values" (Peylet, 1986: 184) would be those that the end of century man enjoys degrading the most. The cliché of the cloistered space is undoubtedly used knowingly to be diverted from its primary functions. This created space, an identity mirror of the esthete, a faithful reproduction of a desire for inwardness, reflects this quest for unification and spiritual elevation felt by the end of the $19^{\text {th }}$ century man. If the character of the androgyne represents, in the same period, the symbol of "the great dream of unity," (Monneyron, 1996: 8) the 
Mickaëlle Cedergren, The monastic Hermitage in the end of century...

HSS, vol. IV, no. 2 (2015): 103-118

monastic character (and not only the bachelor character) (Borie, 2002) is also a powerful symbol too little studied till today. The review of literary inscriptions of the "monastic" space, with the study of its geographical location and its internal time and social functioning, will make it possible to capture the inner movement of literary characters. In all these novelistic introductions, a dominant element emerges: the meticulously disciplined lifestyle of all these characters, methodically organized, not to say "religiously" ordered. Structuring his whereabouts, his meal and sleeping times, his visits, his outings, is already giving shape to time, that is to ritualizing it in order to better control the hermit. To deliberately take on oneself such a lifestyle, that is undoubtedly to create new rules to place oneself beyond the standards and to violate them while building a secured and reassuring environment. But this space, to speak like Jankélévitch, is akin to a "headless body" (Jankélévitch, 1950: 359), a type of "headless monster" (Ibid., 351) where ritualism is blooming. This monastery copy seems well, beforehand, emptied of its contents.

Nevertheless, by sheltering in this enclosed area, these literary characters live in a sacred space, in other words a different space breaking with the surrounding world (Eliade 1965: 25-62).

To begin with Barrès' characters, Philippe and Simon, they move into a property, "an old monastery, whose ruins enclose [them] and ennoble [them]." (Barrès, 1889: 39) This inseparable duo decided to "cut any wires with the world," up to the burning of the postal mail (Ibid: 45). Discovering in "the dilapidated corners of [their] property" (Ibid: 46) a thirteenth cloister equipped with "old cells"( Ibid: 47), they will choose to settle there to indulge in meditation. Their routine life follows a more rigid pattern: Philippe and Simon go down to the cloister every morning and keep silent until dinner at 7 pm (Ibid.: 48). After having a quick breakfast, they spend time at leisure before returning to meditation and to a recreational break in which there will be an alternate time for smoking, walking and playing shuttlecock. At $4 \mathrm{pm}$, they return to the cell. Each day is ended, after dinner, with a careful analysis of daily sensations (Ibid: 49). A strictly ordered organization is established, in order to comply with a monastic rule. 
Mickaëlle Cedergren, The monastic Hermitage in the end of century...

HSS, vol. IV, no. 2 (2015): 103-118

Like the religious orders which "have created soul hygiene" (Ibid: 54), they will also exercise to create "an admirable mechanical" (Ibid : 83) to better worship their Ego, to better develop their "feelings faculties." The "apprentice-cloistered"4 thus seeks self-discipline and establishes a ritual to rise above the laws governing society. To subject themselves to a whole set of laws is according to Philippe "to maintain and to strengthen [their] will" (Ibid: 49) but also to infringe the secular society on those who govern. For them, communion rhymes with asceticism and discipline. Just like religious persons, they "review [their] sins, [their] lack of love" (Ibid.: 68). Philippe wants to explore his ego, dissect his soul, control his emotions and his natural instincts; he wants to mechanize his soul (Ibid.: 97) The enjoyment will also suffer the same fate and comply with the mechanization system, in order to increase the benefits of pleasure (Ibid: 271.) In its turn, the method which, will contribute to giving rise to enthusiasm in the cloistered-apprentice's prayer when prayer gives way to the liturgy (Godo, 2002: 159). The mortal enemy to eradicate is, of course, disordered passions, natural appetites, the unconscious mind (Barrès, 1889: 272sq, 286).

The reproduction of a place and a monastic system establishes an end of century lifestyle able to cultivate a decaying soul: it is the royal road to achieving an internal unification. The settling in St Germain entails "the entrance into the ritual place" (Godo, 2002: 157). By resuming while diverting the spiritual exercises of Loyola, everything is organized there. Time and space are not so much annihilated apart from being only reinvented to make the Barrès character's ego (Ibid: 162-163) grow, safe from any contingency.

This mechanization and this ritualization are revealed with such splendor in Sixte's case. This frenzy of method, rigor that any good scientist must acquire, takes the form of facts and meticulously ordered gestures. This scientist, whom Bourget will make a harsh criticism of, is a "living chronometer" (Bourget, 2010: 291) in Mrs. Greslou's words. Seated from 6 am to write, he had his breakfast at 10 and took his daily walk from 10.30 to noon in the plants garden or sometimes not far from Notre-Dame. From noon to $4 \mathrm{pm}$, he resumed his work. Visits were carefully regulated and restricted like the visits made to a monk and had to take place between $4 \mathrm{pm}$ and $6 \mathrm{pm}$. He had dinner at $6 \mathrm{pm}$ outdoors 
Mickaëlle Cedergren, The monastic Hermitage in the end of century...

HSS, vol. IV, no. 2 (2015): 103-118

and then took a walk up to $8 \mathrm{pm}$. The evening was devoted to correspondence and writing until lights went out at $10 \mathrm{pm}$ Like any monastic life, a weekly rest was taken one day during the week, in this case on Monday (Ibid: 71). He was thus leading a lifestyle, at least formally, identical to that of a monk and this to the extent of following, unknowingly, food prescriptions of meat abstinence on Fridays, a fasting day, according to his ingenious servant's prescription (Ibid: 73).

As for des Esseintes, he does not make any exception to the rule, he who regulated the immutable mealtimes. At $5 \mathrm{pm}$, he had lunch and dinner around 11 o'clock at night and "pecked a small dinner" in the early morning around 5 am (Huysmans, 2004: 56) before going to bed. The menus were at a fixed time and he did not receive any visit (Ibid: 78).

The rule is therefore necessary in the lives of those men as a secure safeguard, those who seek to escape from the world's dangers. This rule is then other than oppressive; it is protective and liberating, it repeals the norm unless it is "the norm [which] gives way to the monastic rule" (Borie 1991: 239). As Eliade writes, "within the sacred enclosure, the secular world is transcended" (Eliade 1965: 29). The Hermitage allows to "move in chaotic homogeneity" [...] and to really live" (Ibid:27) By its structuring function, the hermitage is registered as not only a mastered but also a mastering universe. Through the crucible of this framework a real creative process is triggered. Being no more passive, those intellectual men deploy cerebral and spiritual activity as they become bomo creator. They are now involved in Creation.

\section{Homo creator}

Godo's presentation shows that "submission to the ritual and code of all the gestures, all the feelings and all the thoughts prepares, such as for Ignace de Loyola, the invention of a language" (Godo 2002: 163). The nature of the liturgy lies in the action and "aims to create what it mimes or what it talks about" (Ibid: 166).

One of the keystones that emerges in these three human lives lies in their ability to create, whether literary, scientific or spiritual creation: des Esseintes will make of his life his work, Sixte will present an enormous scientific production (and represents here the antithesis to the useless 
Mickaëlle Cedergren, The monastic Hermitage in the end of century...

HSS, vol. IV, no. 2 (2015): 103-118

and unproductive decadent $)^{5}$ and Philippe will exploit his soul, meditate, write and concentrate on research (Barrès 1889: 42).

To use one of the constructive lines of Barrès' trajectory, we will retain precisely two reasons: "action and creation" (Godo 1997: 196), which explain how the nationalism of the latter is only the fulfillment and the empirical deployment of an individualistic thinking. In Un bomme libre, we are at the time of creation which is confined to the fiction and utopia that Godo calls poiesis. Philippe, the spokesman of Barrès' egotism, rejects the universal moral law of Kant's pure reason and in return exacerbates human passions, passions which he will exercise through these beings that they call perfect since they are close to God. Happy because he was "released from the necessities of action" (Barrès 1889: 90), Philippe meditates, cultivates his desires and his sensitivity, also hoping to "touch God" (Ibid: 119). The equation is simple: the more he experiences emotions, the more his ego increases, and the closer he is to God (Ibid: 121).

The entry into the solitary retreat is also for des Esseintes an "entry into literature." This solitary retreat is no longer realistic, as explained by Jerome Solal:

Puisée à la source flaubertienne, la thébaïde semble littéraire dès l'origine. L'entrée de Des Esseintes dans la thébaïde signe donc en quelque sorte son entrée en littérature. Huysmans poursuit le grand Intertexte. De fait, il attribue au lieu de référence (que les Naturalistes considèrent eux comme l'espace réel de leur étude soi-disant scientifique) une dimension littéraire, c'est-à-dire qu'il lui confère la crédibilité d' 'un pouvoir à la fois absolu et improbable', propre à l'émergence de possibilités circulant bientôt entre le rien, le rêve et les vérités nues (Solal 2008: 176). ${ }^{6}$

The solitary retreat has become a literary place. All the narratorswriters enclosed in a solitary retreat devote themselves to literature, fiction, imagination; they are immersed in a creation process.

Des Esseintes, Philippe and Sixte share the feature of being productive intellectuals. On the one hand, des Esseintes organizes his hermitage to make it "a retreat of thoughts, a kind of chapel" (Huysmans 2004: 100); on the other hand Sixte, an "intellectual hermit" (Bourget 2010: 117) and a "kind of modern Spinoza, so completely identical to 
Mickaëlle Cedergren, The monastic Hermitage in the end of century...

HSS, vol. IV, no. 2 (2015): 103-118

[his] books" (Ibid: 169) will write several scientific works in his apartment. As for Philippe, he will do research and meditate on the works of Ignace de Loyola, Benjamin Constant and Sainte-Beuve, unlike Des Esseintes, who prefers Baudelaire, Barbey d'Aurevilly, Flaubert, de Goncourt, Zola and many Catholic authors. On several occasions, mention will be made of the working qualities of Sixte, this "powerful" (Ibid: 70) worker. The author of Disciple will describe the horizon of his apartment to better highlight "the concentrations of thought" (Ibid: 63) of his tenant and if Sixte's life is ordered in every detail, that is to summarize its essence: "The whole life formula stood in this word: thinking." (Ibid: 70)

Sixte's meditation largely differs from Philippe's spirit, whom this "idolatry [of the] brain" (Ibid: 175) and the thinking and rationalist ego of Sixte horrify him. But, they still have one thing in common. Sixte, just like Philippe, wants to "study the monastic rules to apply them to [his] thinking culture" (Ibidem). His speech is dazzlingly clear, "Yes, I have planned to make my daily meditations, like the monks, on the few items from my philosophical credo, to celebrate each day, like the monks, the celebration of one of my own saints, Spinoza, Hobbes, Stendhal, Stuart Mill [...]" (Ibid: 176). The monastic lifestyle appears thus as the ideal form according to which, in each of those cases, may be deployed the noble work associated with reading and writing, lectio divina to which the monk is invited. The cloister becomes the emblem of the scriptural art.

But the issue goes beyond this; it is not only a matter of meditation and mystical deepening. As subtly emphasized by Jean Borie, "to be a Christian, that will be, for the bachelor, the ultimate ideal for manhood" (Borie 2002: 290). The end of $19^{\text {th }}$ century men will defend that ideal of celibacy because this hermit lifestyle allows them to grow or, rather, to reinstate a masculinity on the way to perdition ${ }^{7}$. This masculinity can only be achieved within a structured territory to counteract the social space in full disintegration. ${ }^{8}$ The monastic vocation is, by definition, the royal road to reach it as a homosocial society. Sixte, a scientific and intellectual archetype, "was determined not to get married, to never go into the world, neither to aspire to honors, nor places, nor reputation" (Bourget 2010: 70). Des Esseintes will make the same bet and the two companions Philippe and Simon will choose to remain single while resorting to some sexual escapades from time to time. Full of monastic 
Mickaëlle Cedergren, The monastic Hermitage in the end of century...

HSS, vol. IV, no. 2 (2015): 103-118

tradition, their lifestyle and their living place try to build a new identity for the end of century man, an identity which is substantially akin to that of the scientific, male not to say anti-feminist, intellectual. This monk's lifestyle is perfectly correlated with the desire of remasculinisation of the end of $19^{\text {th }}$ century man'.

Within the monastic hermitage a modern male identity is thus built. This solitary retreat in which they find each other also represents, without any doubt, a masculine identity ideal by relying on a valid and firm foundation: Christianity. It is this heterotopic place where a masculinity reconstruction is made possible, outside the bourgeois world, outside the time and outside the female world.

\section{The cosmopolitan man}

If the literary character borrows the form of the monastic life, that is to extract this universalism which characterizes it and endorses this cosmopolitan identity which generally suits the monk. Man of God, man of all, outside the world, outlaw, he is free. The end of $19^{\text {th }}$ century character ignores all affiliations, any time, any place. He is confined to that closed space which is, paradoxically, "free from all social constraints". One understands why the characters accept this monastic confinement mode, this seclusion of which one of the natural consequences will be to "suspend the time and to expand the consciousness field" (Godo 1997: 149).

Philippe, whose suffering is that of being "locked in a body and in a century" (Barrès 1889: 77), will however be locked into a cloistered space to "know the universe mind" (Ibid: 57) An aporia that is resolved under the condition of assimilating the cloistered space to a cosmopolitan place, off-time, off-premises, to make it similar to the universality archetype. Philippe aspires besides to erase any separation between his soul and the universe, he does not want to "summarise as such the universe" (Ibid: 54). His programme is clearly stated when he proclaims his desire to "pile up the emotion with so many sciences, to be shaken by the immortal aspect of things" (Ibid: 57).

Philippe and Simon are looking for the cult of the ego, which will be "the most possible complete picture of the universe" (Ibid: 74). Loneliness and meditation will lead them to strip, regenerate to become 
Mickaëlle Cedergren, The monastic Hermitage in the end of century...

HSS, vol. IV, no. 2 (2015): 103-118

the new Adam's man. Philippe's exclamation is revealing: Let's run to loneliness! Let's be newborns! Stripped of our attitudes, forgetful of our vanities and all that is not our soul; truly released, we will create a new atmosphere where we embellish by sagacious experiments" (Ibid: 23) Philippe's programme is ambitious; the challenge is to become "a free man" (Ibid: 55) in full possession of his feeling faculties. The emergence of the new man, "the ego creation" goes through "this constant concern to keep in touch with the unlimited" (Godo 1997: 148). In line with this thinking, it is easy to foresee how this proximity with the unlimited is made possible through the timeless and silent character of places. Any trace of temporality, any trace of orality tends to be erased.

The obsession of silence which prevails in the solitary retreat is perfectly exemplified backwards. Des Esseintes preserves his enclosure from any noise and any temporal violation. He is attentive to ensure that silence be preserved up to making his couple of servants wear "thick felt slippers" and "cushion their floor with deep carpets" (Huysmans 2004: 65). To avoid any unnecessary word, des Esseintes organized a coding system in which each ring meant something (Ibid: 55). Philippe and des Esseintes also want to leave the influence of time, they want above all to transcend time (Peylet 198: 138). If des Esseintes chooses to reproduce a pseudo-oratory in his bedroom, that is to "break with the irritating memories of his past life" (Huysmans 2004: 101), he who "had decided not to introduce in his cell larvae of repugnance or regrets" (Ibid: 89), the end of century men are looking specifically to "splitting from the future and the present that becomes the future" (Peylet 1986: 139). Des Esseintes and Simon do not kill the time, which would be against liturgy and counterproductive, but rather go beyond by borrowing from the liturgical devices the way of making time eternal. The text is more expressive: Des Esseintes admires the painting by Gustave Moreau because he "seemed to also have wanted to affirm his will to stay out of centuries, not to specify origin, country, period" (Huysmans 2004 : 92). Simon, Sixte and des Esseintes have all three mechanized their lifestyle up to ritualizing their movements. Thus, they entered another era, the eternal sacred time. This spiritual aspect is considerably at work if one examines the geographical location of hermitages. 
Mickaëlle Cedergren, The monastic Hermitage in the end of century...

HSS, vol. IV, no. 2 (2015): 103-118

\section{The monastic space, a super-natural place}

The site indicates the super-natural aspect of the monastic enclosure and the deep desire of the character to rise. The view of the surrounding nature is not insignificant and it highlights the high position, both physical and spiritual, of the hermitage.

To begin with Sixte's apartment, the narrator will make an analogy with the cloisters usually "built in locations that allow the eye to embrace a large amount of space" (Bourget, 2010: 63). Sixte's refuge, located indeed on the fourth floor, flies over the horizon, in this case a natural area that consists of a garden of plants. In Un homme libre, the same conclusion can be drawn: the property "occupies the top and the skinned slopes of a volcanic coast" (Barrès 1889: 39). The St-Germain hermitage is "located pretty much on the limit between the plain and the mountain" (Ibid: 125). Nothing is more explicit than this panorama where nature appears parched and impoverished, "our windows dominated a vast basin of plowed land, without water, and whose solemn curve led to the silent forests horizon" (Ibid: 40) Des Esseintes will live in turn in the heights by choosing "a shack for sale, on top of Fontenay-aux-Roses, in a secluded location, without neighbors, near the fort" (Huysmans 2004: 46). This natural setting below is dominated by the cloistered space. Nature is nevertheless neither stifled, nor abused (Peylet 1986: 33); it is overflown, surpassed, exceeded (Des Esseintes, won't he say that "nature has had its day" and that "the time has come to replace it, as much as possible, by the artifice" (Huysmans 2004: 60)?). Finally, it is perhaps not so much an "against-nature" principle on which we should insist but on the supernatural (aspect emerging from the texts Peylet 1986: 150).

\section{The monastic Hermitage or the architect of the new man}

After this analysis, the end of $19^{\text {th }}$ century literary character seems to live in the world but does not belong to this world, which is probably what the monastic hermitage symbolises better by materialising an elsewhere, a beyond. If characters borrow this space, it is to leave room for a creative masculinity and to transform the end of century fragmented man into a unified human being. Therefore, choosing a monastic place means trying to reach a human and spiritual elevation. In the depths of these hermitages, everything seems suspended, except for the intellectual 
Mickaëlle Cedergren, The monastic Hermitage in the end of century...

HSS, vol. IV, no. 2 (2015): 103-118

and spiritual production in the form of reading, writing or meditating. More than a convent atmosphere, these places have already been endowed with a spirit and invite characters to the mysticism table.

Finally, we perceive that the spiritual quest is what worries the hearts of these men. Coming back to des Esseintes, one just feels a hint of regret in his voice when he confesses to knowing "that he would never have the true Christian spirit of humility and penance" (Huysmans 2004: 112). He feels that "wrapped in a convent atmosphere in an incense scent that intoxicated his head, he had the nerves exalted and by an association of ideas, these books [Latin works] had come to repress the memories of his life as a young man, by calling into light those of his youth, with the Fathers" (Ibid: 113). Falling prey to his doubts and his suspicions, the inner feelings of the character shake and his hermeticism cracks (Ibid: 114). Already in the middle of the novel, Huysmans' character fights against himself, against the tentacles of this cloister that are ultimately rooted in him and dispossess him (Ibid: 113). Des Esseintes wanted to reproduce this monastic framework, to shape it according to his needs without being aware of the fact that this environment could also shape him. His plea at the end of the book, the cry of the poor repentant sinner, announces the new literary character which will be Durtal in the trilogy, "Lord, have mercy on the Christian who doubts, the unbeliever who would like to believe [...]" (Ibid: 249).

This moment of doubt and dizziness after his novelistic pilgrimage can also be observed with Sixte, the character certainly less inclined to the religious spirit. Seized by "a feverish and unexplainable anxiety", remorseful, he questions his role with Greslou and realizes that the truth has been the engine for his intellectual search, a truth that is very similar to the Christian one. His thinking is burning, "when he took the pen, why had he written, to serve what purpose, if not the truth? For the truth he had sacrificed everything: wealth, place, family, health, love, friendships. And that was even taught by Christianity, the most penetrated doctrine of ideas contrary to his own?" (Bourget, 2010: 302). The novel ends with a prayer, that of Our Father.

From the reading of the texts will emerge a clear match between the monastic space and the "inwardness of the soul"10 of the literary character. If on the one hand the soul builds the environment in which it 
Mickaëlle Cedergren, The monastic Hermitage in the end of century...

HSS, vol. IV, no. 2 (2015): 103-118

is immersed to make of it an "architecture" of the ego, "a materialization of his innermost being" (Godo 2007: 120 and Peylet 1986: 145) and to become synonymous with the place in which it is immersed, on the other hand the environment appears to be the engine of action that is likely to shape characters. This perhaps more unexpected interaction is what Rodenbach announced in the warning of his novel Bruges-la-morte, "In this passionate study, we also wanted mainly to evoke a City, the city as an essential character, combined with moods, advising, deterring, determining to act. [...]. That is what we wanted to suggest: the City orienting an action; its urban landscapes, not only as backdrops as descriptive themes somewhat arbitrarily chosen, but related to the same event of the book" (Rodenbach 1889: 10-11).

This faith, of which we only see a few shoots, has "branched in the soul" (Huysmans 2004: 114) of des Esseintes and Sixte so as to rehabilitate a place emptied of its essence. With these literary examples, the demonstration is conclusive: the container cannot do without its contents. As des Esseintes puts it, this frantic quest for artifice is only the hidden face of another, more real quest: that of an ideal life, a distant and still inaccessible bliss (Ibid: 115). We join closely Emmanuel Godo's line of thought, who concludes, in the case of Huysmans: "we do not monkey a religious person with impunity; the pantomime of the recluse brings him closer, more than he thinks himself, to this monastic way in which he first made a game" (Godo 2007: 142).

The cloister offers those who want to find a material and spiritual refuge its "real space, [its] liturgy, [its] culture, that [finally] the conviction of faith authenticates" (Vilcot 1988: 51). That is probably why the end of the $19^{\text {th }}$ century man prefers this cloistered space to the mystical solid foundation. As emphasised by Gérard Peylet, when the confined space images are valued by Huysmans, they show "enrichment, conquest or hope to conquer a substance, a substantial treasure, the deep quality being not what encloses, but what is enclosed" (Peylet 1987: 29).

This space will also be methodical, mechanical and scientific, as well as liberating and creative. Precisely because of its immutable, universal, timeless character, this space is subversive: it disturbs, it shakes and gives way to something else. Chosen for their signifying, monasteries became the signified whose material has burgeoned and flourished under its own 
Mickaëlle Cedergren, The monastic Hermitage in the end of century...

HSS, vol. IV, no. 2 (2015): 103-118

control system (Jankélévitch 1950: 353). In the hollow of this inwardness, this stability, this fence, an opening is created. The character takes a sudden turn. It is this shift that will take the novelistic form of doubt and confession. In other words, this cloistered space, beyond a simple projection, is meant to be for the writer the place for a possible exploration and creation, that of a poesis, where the switch to a different literature can be performed, thus confirming the death of naturalism and paving the way to a modern literature, that of mystical naturalism. A model of heterotopia, called illusion, whose function is to "denounce as still more illusive the whole real space" (Foucault 1994: 761), the solitary retreat has become a real space11, a "compensation space" (Foucault 1994: 761), a genuine "attempt to repair , to restore nature" (Peylet1986: 150) where a quest for the Absolute is apprehended and sought to be reached.

The monastic hermitage, incidentally the ego architecture, has emerged as the great architect of the modern ego. It is this "stone" that has known "to respond obediently and instantly to the imagination intentions, - so obediently even that it sometimes succeeds in being ahead of them, and in addressing man's wishes before he has got time to formulate them" (Jankélévitch 1950: 353). The hermitage is no doubt a prophetic sign announcing the future of an ideal literature.

\section{References}

Barrès, M. Un homme libre. Paris: Perrin et $C^{\text {ie }}, 1889$.

Bataille, G. La Littérature et le mal. Paris: Gallimard, 1957.

Borie, J. Le Célibataire français. Paris: Grasset, 2002.

Borie, J. Huysmans, Le Diable, le célibataire et Dieu. Paris: Grasset, 1991.

Bourget, P. Le Disciple. Paris: Le Livre de poche (classiques), 2010.

Cedergren, M. \& Cadars, M.-C., Le Naturalisme spiritualiste. Développement et rayonnement. Paris: Classiques Garnier, 2012a.

Cedergren, M. "Le monastère ou le refuge hors ville - une tentative de remasculinisation." Strindberg et la ville. Eds. H. Balzamo \& S. Briens. Strasbourg: Université de Strasbourg, 2012b, 133-146.

Cedergren, M. "L'univers cloîtré ou la création d'un 'contre-monde'." Villes invisibles et écritures de la modernité. Ed. A. Choné. Paris: Editions Orizons, 2012c, 201-218.

Eliade, M. Le Sacré et le profane. Paris: Gallimard, 1965. 
Mickaëlle Cedergren, The monastic Hermitage in the end of century...

HSS, vol. IV, no. 2 (2015): 103-118

Foucault, M. "Des espaces autres." Dits et écrits 1954-1988. Eds. D. Defert \& F. Ewald. Paris: Gallimard, 1994.

Godo, E. Huysmans et l'évangile du réel. Paris: Cerf, 2007.

Godo, E. "La morale fissurée : Le Disciple de Paul Bourget." Amoralité de la littérature, morales de l'écrivain. Ed. J.-M. Wittmann. Paris : Champion, 2000.

Godo, E. "Liturgies intimes de l'égotisme barrésien. " Littératures, rites et liturgies. Ed. E. Godo. Imago, 2002.

Godo, E. "Maurice Barrès et la connaissance par les gouffres." Ego scriptor : Maurice Barrès et l'écriture de soi. Ed. E. Godo. Paris: Éd. Kimé, 1997.

Godo, E. "Postface - De l'individualisme au nationalisme, réflexions sur la cohérence de l'œuvre de Maurice Barrès." Ego scriptor: Maurice Barrès et l'écriture de soi. Ed. E. Godo. Paris: Éd. Kimé, 1997.

Grauby, F. Huysmans à côté et au-delà. Leuven: Peeters-Vrin, 2001.

Huysmans, J.-K. A rebours. Paris: GF Flammarion, 2004.

Jankélévitch, V. "La Décadence." Revue de Métaphysique et de Morale 50 (1950).

Limat-Lettelier, N. "Enjeux de l'œuvre après la conversion." L'androgyne décadent: mythe, figure, fantasmes. Eds J.-P. Bertrand, S. Duran et F. Monneyron. Grenoble : Ellug, 1996.

Peylet, G. "Derrière la symbolique chrétienne du 'livre de pierres', le symbolisme caché du 'cloître' dans La Cathédrale." Bulletin de la Société Huysmans 80 (1987): 19-32.

Peylet, G. Les Évasions manquées ou les illusions de l'artifice dans la littérature "fin de siècle ». Paris : Champion, 1986.

Rodenbach, G. Bruges-La-morte. Paris : Flammarion, 1889,

Solal, J. Huysmans et l'homme de la fin. Caen : Lettres modernes Minard, 2008.

Vilcot, J.-P. Huysmans et l'intimité protégée. Paris : Lettres modernes, 1988.

1 All quotations from the works of Huysmans, Barres and Bourget were translated by Dr. Grégoire Njejimana.

2 "He had thus the benefits of confinement and avoided its disadvantages: the soldiery discipline, lack of health care, filth, promiscuity, monotonous idleness. Just as he had done with his cell, a comfortable and slightly warm room, so he had made his life normal, soft, surrounded by well-being, busy and free".

3 See M. Cedergren \& M.-C. Cadars (2012) for more information about mystical naturalism.

4 Expression taken from Emmanuel Godo in "intimate Liturgies of Barres egotism" Literature, rites and liturgies. Ed. E Godo, Imago, 2002157. 
Mickaëlle Cedergren, The monastic Hermitage in the end of century...

HSS, vol. IV, no. 2 (2015): 103-118

${ }^{5}$ View Emmanuel Godo's reflection on the paradoxical nature of decadent character of Sixte and its similarities with the character of Des Esseintes in "La morale fissurée: Le Disciple de Paul Bourget", Amoralité de la littérature, morales de l'écrivain. Paris: Champion, 2000, 37-38.

6 "Drawn from Flaubert's source, the solitary retreat seems to be literary from the outset. Des Esseintes' entry in solitary retreat signs then somehow his entry into literature. Huysmans continues the great Intertext. In fact, he credits the reference location (that the Naturalists consider as the real space of their socalled scientific study) a literary dimension, that is to say, he gives it the credibility of an absolute and improbable power, unique to the emergence of opportunities soon circulating between the nothing, the dream and the bare truths" (translated by G. Njejimana).

${ }^{7}$ See Cedergren M. (2012b, c) about the monastic space and the symbolic in Strindbergs works.

8 "In the idea of manhood, there was always the image of a man who, within his limits, wisely, but without fearing and thinking, knows how to put himself above the law" (G. Bataille 1957: 147 quoted by Jean Borie 2002: 255).

${ }^{9}$ See M. Cedergren, 2012 b: 133-146.

${ }^{10}$ See the article cited by Gérard Peylet (note 6) on the hidden symbolism of the "cloister" in $\mathrm{La}$ Cathédrale in which he shows how finely the spiritual journey of Huysmans [then converted] develops through the confined space. "This mystical way he [Huysmans] borrows humbly, secretly, is not that of the big jump in the absolute, of catharsis, the old man's brutal depriving [...]. Hidden, underground, nocturnal, it allows the fearful believer to mature his spiritual journey. It exalts inside the privacy archetype"(Peylet 1987: 23).

${ }^{11}$ See the concept of sacred space in Mircea Eliade's Le Sacré et le profane (1965: 25-62).

\section{Biographical note}

Mickaëlle Cedergren: Associate Professor of French at the University of Stockholm. Director of an International Research Project on Franco-Swedish Cultural Transfers in the Twentieth Century in collaboration with Paris-IV (2011-2014). Among her publications: L'Écriture biblique de Strindberg (2005) and studies of the religious imagination in the late nineteenth century. Since 2014, she has worked with Ylva Lindberg on a project The Voice of the Periphery. Transmission and Reception of French Literatures in the 21st Century in Sweden, Romania and Burundi. She is co-editor of three groups: The spiritualist naturalism in Europe (2012), Strindberg inheritance (2013) and Intercultural Mediations, paths and exchanges between France and Sweden from 1945 to the present (in print). 